DOI https://doi.org/10.30525/978-9934-26-065-0-10

Bogdan Kryvolapov,

PhD in Law

Associate Professor of Private International Law Chair Institute of Institute of International Relations Taras Shevchenko National University of Kyiv

ORCID iD: 0000-0002-5933-7850

\title{
CIVIL LEGAL REGULATION OF MOVABLE CULTURAL VALUES CIRCULATION IN UKRAINE
}

\begin{abstract}
The article deals with theoretical and practical problems of the circulation of movable cultural values in civil law.

The cultural values as objects of civil rights are explored. The qualification of cultural values as things in civil law is made considering their features.

The author analyzes the specifics of transactions with cultural values. Particular attention is paid to the contract of sale of cultural values, including the sale through an auction. The author has identified that the distinctive feature of the Ukrainian legislation on contracts of sale of cultural values is the possibility of the preemptive right of the state to purchase them.

The protection of property rights for cultural values is examined separately. It is claimed that the vindication claim is the main civil law manner to protect property rights for cultural values. It is found out that the problem of a bona fide beneficiary arises in the protection of property rights to movable cultural values.

It has been determined that the representation based on an agency agreement is used to purchase and sell cultural values at auctions.

Keywords: cultural values, civil circulation, objects of civil rights, contract of purchase and sale of cultural values.

Problem statement. According to different reports the annual Ukrainian art market turnover is about 150-200 million dollars a year [2]. Of course, some stagnation due to the pandemic has been observed over the last year, but the last sales at the "Zolotoe Sechenie" auction [7] and other auctions indicate the resumption of this market.
\end{abstract}


Bogdan Kryvolapov. Civil legal regulation of movable cultural values circulation in Ukraine

Beyond all shadow of doubt, the development of the Ukrainian art market requires the appropriate rules. However, Ukrainian legislation on this issue is inconsistent and contains many gaps. Many legal scholars point to its fragmentation and the conflicts existing $[6$, p. $71 ; 8$, p. $63 ; 11$, p. 4]. Another problem of Ukrainian legislation is the lack of uniform terminology regrading cultural values [18, p. 177]. That explains why Civil law researchers have shown an increased interest in this problem in recent times.

Analysis of basic research and publications. Theoretical and methodological foundations of this article are the works of domestic and foreign scientists: T. Dudenko [3; 4], V. Zverikhovska [5; 6], I. Kolodiy [8], E. Korol [9; 10], O. Menska [11], O.Tsyhanok [18] and other scientists.

The purpose of this article is to explore the specific regulation of movable cultural values circulation in the Civil law of Ukraine.

Presentation of the basic material of the article. In order to identify specific features of transactions with cultural values first of all it is necessary to consider cultural values as objects of civil rights. According to Article 177 of the Civil Code of Ukraine (CCU) the objects of civil rights are things, including money and securities, other property, ownership rights, results of work, services, results of intellectual and creative activity, information, as well as other tangible and intangible welfare [17]. So, cultural values are the things, i.e., items of the material world with respect thereto civil rights and obligations may be arisen (article 179 of the CCU).

Under Article 181 of the CCU the things can be movable and immovable. If cultural values are immovable (res immobiles), then according to Art. 182 ownership rights and other property rights to immovable things, restrictions thereof, their emergence, transfer and termination are subject to state registration [17]. What is certain is that immovable cultural values are regulated by the Law of Ukraine on Protection of Cultural Heritage of July 8, 2000 № 1805-III [16]. As the article does not engage with immovable cultural property circulation, the author will not conduct a detailed analysis of the provisions of the above Law.

If things can be freely moved in space, they are recognized as movable (res mobiles) by Ukrainian Civil law [17]. It is obvious that cultural values may be movable things. The law of Ukraine Law of Ukraine № 1068-XIV “On Export, Import and Return of Cultural Values" of September 21 provides a detailed list of movable cultural values [14]. 
According to T. Dudenko, the classification of things for singles (simplices) and composite things (summae) is very important for cultural values circulation [3, p. 61]. Single things are natural objects which appear as one thing (e.g., book, table, picture, sculpture). It stands to reason that in certain circumstances such things can be cultural values. According to Part 1 of Article 188 of the CCU if several things form a single entity, thus allowing its use according to its designation, they shall be considered as one thing (a compound thing) [17]. Such things consist of various objects that are not physically connected to each other. Antique service or a furniture set are good examples of movable cultural values as compound things. It is believed that such a term as «collection» can be used for movable compound cultural values. [3, p. 61]. Transaction made with regard to a compound thing shall extend to all its constituents, unless otherwise envisaged by the agreement.

Another important classification of things is into identified by individual or generic characteristics. Article 184 of the CCU provides that thing shall be identified by individual characteristics (species) if it possesses the unique inherent features that distinguish it from other similar things and individualize the thing [17]. The Civil Law doctrine considers such things as unique, non-fungible, which exist in a single copy [12, p. 115]. In this case, cultural values are classic example of things that are determined by individual characteristics (Ivan Marchuk's painting «Golden Night», Auguste Rodin's sculpture «The Thinker», the Scythian pectoral from «Thick Grave», etc.). As it was already mentioned above, things identified by individual features are non-fungible. It means that the loss of such a thing terminates any obligation related to it (transfer, transport, preserve, etc.). According to Part 2 of the Article 184 of the CCU a thing shall be identified by generic features if it has the features inherent to all other things of the same gender and is measured by a number, weight and measure [17]. Such things do not have any special characteristics and are replaceable (grain, sugar, oil). The principle of genus non perit (the genus does not perish) is applied to generic things [12, p. 115]. Legal effect of such classification is that the loss or deterioration of a fungible thing is discharged by the delivery of another similar thing. So, cultural values are not things identified by generic features.

Things can also be principal and accessory. Principal thing is used independently from other things. An accessory is a thing designed for servicing another (principal) thing and related to it by a common designation. Accessory has 
Bogdan Kryvolapov. Civil legal regulation of movable cultural values circulation in Ukraine

no value by itself. A classic example of principal thing and accessory is a sheath and a dagger, a box and a key, a picture and a frame, etc. According to Part 2 of Article 186 of the CCU an accessory shall follow a principal thing, unless otherwise established by the agreement or the law [17]. However, it must be borne in mind that sometimes accessory may be more valuable than principal things and, accordingly, have a greater cost.

Civil law distinguishes between consumable (res quae usu con sumuntur) and non-consumable (res quae usu non consumuntur) things. Under Article 185 of the CCU a thing is consumable if it is destroyed or cease to exist in its initial form as a result of one-time use (food, fuel). A thing shall be considered non-consumable if it is designed for repeated use and preserves its initial form over a long period of time (books, clothes, cars, furniture) [17]. The legal consequence of this classification is that the subject of some transactions (leasing, renting) are only non-consumable items. Thus, it is obvious that cultural values are non-consumable things.

In the theory of civil law, things can be in free circulation (res in commercio), restricted in circulation, withdrawn from civil circulation (res extra commercium). In most cases, things are in free circulation and can be freely alienated. Things that cannot be the subject of transactions (objects of state property, subsoil, air, objects of historical and cultural heritage, etc.) are defined as withdrawn from civil circulation. As a rule, the legislation provides a detailed list of such things. Things with restricted circulating capacity may belong only to certain persons under special permits (licenses) and their circulation is governed by special rules.

Cultural values may be in free circulation and be the subject of different transactions. But also, these items can be withdrawn from civil circulation. For example, according to Article 152 of the Law of Ukraine «Law of Ukraine On Museums and Museum Business» of June 29, 1995, museum objects, museum collections that are state part of the Museum Fund of Ukraine, are not subject to disposal, except for exchange for other museum objects, museum collections, museum collections [15]. Thus, the state part of the Museum Fund is withdrawn from civil circulation. As far as the non-state part of the Museum Fund of Ukraine, it is necessary to pay attention to the provisions of Part 4 Article 152 of the above law, according to which the non-state part of the Museum Fund of Ukraine and 
objects of museum value to be included in the non-state part of the Museum Fund of Ukraine may not be the subject of the pledge if the pledgee is a foreign citizen or stateless person in Ukraine [15]. In this case, we are talking about the restriction of civil circulation.

Summing up the analysis of cultural values as objects of civil law, it should be noted that the Civil Code of Ukraine also provides for other types of things that can hardly be cultural values. As I. Kolodiy notes, animals (which are objects of civil rights) cannot be referred to as antiques, because such objects can be only inanimate things [8, p. 64]. This assumption is appropriate and can be applied not only to antiques but also to any other things that may be considered as cultural values. It is necessary to point out that cultural values also cannot be fruits and incomes, which are regulated by Article 189 of the CCU, and the company as a single property complex, the status of which is provided by Article 191 CCU [17].

The regulation of transactions with cultural values is particularly important for the determination of its circulation-specific features. First, it worth noting that such transactions should be concluded in a written form. This conclusion can be drawn from the general content of Part 3 of Article 208 the CCU. Notarization of such transactions is not required [17]. In the literature it has been suggested that transactions with cultural values should be concluded in a special written form [6, p. 72]. It can be agreed with T. Dudenko's proposal that it is necessary to notarize transactions with the movable cultural property the value of which exceeds 50 times the minimum salary [4, p. 74] because in this case, both parties will be protected.

Many Ukrainian scholars hold the view that the most popular transactions with movable cultural values are contracts of sale, contracts for transfer for usage, commission contracts [4, p.73; 6, p.12]. Purchase and sale deals of movable cultural property is made by concluding ordinary contracts or through auctions [4, p. 73]. It should be mentioned that there are special rules for the purchase and sale of movable cultural property in Ukrainian legislation. The provisions of $\mathbb{} 1$ of Chapter 54 of the CCU [17] apply to such contracts. It is possible to agree with the opinions of some researchers that the Ukrainian legislation needs special rules for the purchase and sale of cultural property [4, p. 74]. V. Zverikhovska has suggested the additional special registration for transactions with movable cultural values [6, p. 71]. There is some doubt about this proposal. It is a well-known fact that 
Bogdan Kryvolapov. Civil legal regulation of movable cultural values circulation in Ukraine

over-regulation makes any market less transparent. Hence, it is possible to assume that the best solution is to notarize only certain category of movable cultural values transactions.

It is noteworthy that some rules concerning the circulation and sale of movable cultural property provide for the preemptive right of the state to acquire them. An example is Part 5 of Article 152 of the Law of Ukraine «On Museums and Museum Business». According to this article in case of sale of museum objects, museum collections, museum collections belonging to the non-state part of the Museum Fund of Ukraine, the state has a preemptive right to purchase them [15]. The similar norm, but less imperative, is provided by the Article 20 of the Law of Ukraine «On export, import and return of cultural property from 21.09.1999 № 1068-XIV, according to which the authorized state agency after the state examination may decide to purchase the cultural property declared for export for the state part of the museum, library and archival funds if it is necessary [14].

Auctions play an important role in the circulation of cultural values. It is claimed that this method of disposal is one of the most popular ways to acquire ownership of these objects and auctions, in this case, act as agents [4, p. 76]. As noted by M. Alyabyshev there are three stages of auctions: a) preparatory stage (preparation and announcement of the auction); b) bidding; c) results of the auction According to this author, violation at each stage can lead to the invalidity of all the auction procedure [1, p. 9]. In Ukraine, the purchase and sale of movable cultural property through auctions is regulated by the Rules of trade in antiques, approved by the Order of the Ministry of Economy and European Integration of Ukraine, the Ministry of Culture and Arts of December 29, 2001 (hereinafter the Rules) [13]. According to paragraph 3.3. of the above Rules, the owner of antiques authorizes the organizer of the auction to sell these items for a fee, the amount of which is determined by agreement of the parties as a percentage of the selling price [13]. Logic would suggest that that these Rules are based on the Agency Agreement which is regulated in detail by Chapter 68 of the CCU [13].

Civil law regulation of the circulation of cultural property, of course, includes issues of protection of property rights to the above objects. In the civil law doctrine, the protection of property is based on three claims: rei vindicatio, action negatoria, and action for recognition of property rights. Rei vindicatio claim is a real action by means of which the owner of an item, who lost possession of 
it, sued the possessor for recovery [12, p. 333]. Action negatoria is a claim of the owner to eliminate unlawful, continuing actions that prevent him from utilizing property [12, p. 336]. A claim for recognition means that the property owner can bring an action for recognition of his property right if this right is contested or is not recognized by another person or in case he lost the document proving his property right. Rei vindicatio is the most important means of protecting property rights. E. Korol states that rei vindicatio is the main civil way to protect the right of property of cultural values [9, p. 78-79]. This claim is regulated in detail by the Civil Code of Ukraine, Article 387 of which provides that the owner has the right to recover his/her property from the person that possessed it illegally without any lawful ground [17]. The specific of this claim is that the thing is usually not seized from a bona fide beneficiary. According to Article 388 of the CCU, a bona fide beneficiary returns cultural property to the owner only if it was stolen, lost, or retired from the possession of the owner or the person to whom the owner transferred the property into possession beyond his will by other way [17]. The problem of bona fide beneficiary of cultural property is so important that there is a special norm in Law of Ukraine On Export, Import and Return of Cultural Values. Under Article 32 of above law bona fide beneficiaries are naturals or legal companies which did not know and could not know that cultural values had been stolen or exported illegally. The second part of this article provides that illegally purchased or exported cultural values should be returned to an owner. In this case a bona fide beneficiary has right to compensation [14]. The fact that the bona fide beneficiary has the right to compensation by this law is positive. But the problem is that current Ukrainian legislation does not specify how a bona fide beneficiary should obtain compensation and its amount.

One should note here also that the jurisprudence on the return of cultural property by a bona fide purchaser to the owner is inconsistent. E. Korol gives examples of two court decisions that demonstrate different approaches in solving this problem. In the first case, an American court considered a lawsuit filed by the German government for the return of two works by A. Dürer (portraits of Hans Tucher and Felicitas Tucher). The portraits were stolen from Schwarzburg Castle by an American soldier in 1945, exported into the United States illegally and sold to New York lawyer E. Elikofon. In 1969, the German government found out the location of the paintings and filed a lawsuit to return the paintings. The American 
Bogdan Kryvolapov. Civil legal regulation of movable cultural values circulation in Ukraine

court upheld the claim and the fact of good faith of E. Elikofon was not considered at all, as the painting was stolen. In the second case an English court awarded the exact opposite decision based on the application of Italian law. Japanese works of art were stolen from a private collection in England and turned to be in Italy. A bona fide Italian collector purchased them and then decided to sell these works at the Christie's auction. The owner of the stolen valuables learned about this and filed a lawsuit to return his property. The court dismissed the claim motivating that the defendant is the rightful owner due to the bona fide acquisition of these items according to the civil law of Italy [10, p. 20-21]. The examples show the judicial practice is controversial

Recently, some authors have suggested that the owners of cultural property should have the right to claim property from someone else's illegal possession in any case, regardless of the good faith of the purchaser [9, p. 98]. It is hardly possible to agree with such a point of view. A bona fide beneficiary is an participant in the civil circulation of cultural values, who became a defendant in a rei vindicatio for reasons beyond his control. Moreover, the situation may arise because of the negligence of the plaintiff. Such inequality of rights can have a negative impact on the functioning of the market of cultural values, even if a bona fide purchaser is compensated.

Conclusions. Summing up the results, a number of conclusions can be drawn:

1. The latest studies in civil law regulation of the circulation of cultural values are focused on three aspects: cultural values as an object of civil law; specifics of transactions with cultural values; protection of cultural property rights.

2. According to Civil law doctrine movable cultural values are things identified by individual characteristics, non-consumable. These things can be simple and compound things, principal things and accessories. Movable cultural values can be in free circulation, limited in circulation, withdrawn from civil circulation. It means certain legal consequences for transactions with these objects.

3. Sales contracts are the most popular transactions with movable cultural values. Ukrainian law does not contain any special rules for the purchase and sale of movable cultural property. The specificity of the legal regulation of such contracts is that in some cases the state has the preemptive right to purchase them. The purchase and sale of movable cultural values are made by concluding ordinary contracts or through auctions. 
4. Auction is the most popular way to acquire ownership of cultural property. The purchase and sale of cultural property at auctions is based on agency agreement.

5. The main civil law way to protect the ownership of cultural property is rei vendicatio. However, the protection of the ownership of movable cultural property raises the problem of a bona fide beneficiary, which has not yet been fully resolved, is interpreted ambiguously in different legal systems, and requires further interdisciplinary research.

\section{REFERENCES}

1. Aljabyshev M. S. (2009) Osoblyvosti ukladennja doghovoriv na aukcioni : avtoref. dys. ... kand. juryd. nauk [The peculiarities of conclusion of the treaties on the auction : extended abstract of candidate's thesis] : 12.00.03. Kyjiv, 2009. (in Ukrainian).

2. Art banking [Art banking.]. Available at: https://ua.gs-art.com/services/ art-banking/ (accessed 4 August 2021). (in Ukrainian).

3. Dudenko T. V. (2017) Klassifikatsiya kulturnikh tsennostey kak obektov grazhdanskikh prav [The classification of cultural values as objects of civil rights]. LEGEA SI VIATA, no. 1/2(301), pp. 60-64. (in Russian).

4. Dudenko T. V. (2019) Zaghaljna kharakterystyka doghovoru kupivli-prodazhu kuljturnykh cinnostej [General characteristics of the cultural values purchase agreement]. Pravo ta innovacijne suspiljstvo, no. 1, pp. 73-79. (in Ukrainian).

5. Zverikhovsjka V. F. (2015) Kuljturni cinnosti jak ob'jekty cyviljnykh prav : avtoref. dys. ... kand. juryd. nauk [Cultural values as objects of civil rights : extended abstract of candidate's thesis] : 12.00.03. Odesa. (in Ukrainian).

6. Zverikhovsjka V. F. (2018) Osoblyvosti doghovoru kupivli-prodazhu kuljturnykh cinnostej [Specific features of the contract of sale of cultural values]. Jurydychnyj visnyk, no. 1, pp. 71-78. (in Ukrainian).

7. Kartynu Ivana Marchuka prodano na aukcioni za rekordnu sumu [Ivan Marchuk's painting was sold at auction for a record amount]. Available at: https://zn.ua/ukr/CULTURE/kartina-ivana-marchuka-prodana-naauktsioni-za-rekordnu-sumu.html (accessed 4 August 2021). (in Ukrainian).

8. Kolodij I. M., Cherednychenko I. S. (2017) Cyviljno-pravove reghuljuvannja antykvariatu v Ukrajini [Civil regulation of antiques in Ukraine]. Porivnjaljnoanalitychne pravo, no. 2, pp. 63-66. (in Ukrainian). 
Bogdan Kryvolapov. Civil legal regulation of movable cultural values circulation in Ukraine

9. Korol E. L. (2014) Vozvrashchenie kulturnykh tsennostey: sootnoshenie chastno-pravovykh i publichno-pravovykh nachal [The return of cultural property: the relationship between private law and public law principles]. Grodno : GrGU. (in Russian).

10. Korol E. L. (2011) Spory o kulturnykh tsennostyakh: problemy opredeleniya primenimogo prava [Cultural Values Disputes: the Problem of Determining Applicable Law]. Zhurnal mezhdunarodnogo prava $i$ mezhdunarodnykh otnosheniy, no. 1, pp. 19-24. (in Russian).

11. Mensjka O. A. (2015) Kuljturna spadshhyna jak ob'jekt cyviljnykh prav : dys. ... kand. juryd. Nauk [Cultural heritage as an object of civil rights (PhD Thesis)] : 12.00.03. Kyjiv: NaPPO. (in Ukrainian).

12. Pidopryghora O. A., Kharytonov Je. O. (2009) Rymsjke pravo [Roman law] : pidruchnyk. Kyjiv : Jurinkom Inter. (Ukrainian).

13. Pravyla torghivli antykvarnymy rechamy, zatverdzheni Nakazom Ministerstva ekonomiky ta z pytanj jevropejsjkoji integhraciji Ukrajiny, Ministerstva kuljtury i mystectv vid 29 ghrudnja 2001 r. №. 322/795 [Rules of trade in antiques, approved by the Order of the Ministry of Economy and European Integration of Ukraine, the Ministry of Culture and Arts of December 29, 2001, no. 322/795]. Available at: https://zakon.rada.gov.ua/laws/show/z005802\#Text (accessed 26 July 2021). (in Ukrainian).

14. Pro vyvezennja, vvezennja ta povernennja kuljturnykh cinnostej : Zakon Ukrajiny vid 21 veresnja 1999 r. № 1068-XIV [Law of Ukraine On Export, Import and Return of Cultural Values of September 21, 1999, no. 1068-XIV]. Available at: https://zakon.rada.gov.ua/laws/show/106814\#Text (accessed 26 July 2021). (in Ukrainian).

15. Pro muzeji ta muzejnu spravu : Zakon Ukrajiny vid 29 chervnja 1995 roku № 249/95-VR [Law of Ukraine On Museums and Museum Business of June 29, 1995, no. 249/95-VR]. Available at: https://zakon.rada.gov.ua/ laws/show/249/95-\%D0\%B2\%D1\%80\#Text (accessed 25 July 2021). (in Ukrainian).

16. Pro okhoronu kuljturnoji spadshhyny : Zakon Ukrajiny vid 8 chervnja 2000 roku, № 1805-III [Law of Ukraine On Protection of Cultural Heritage of June 8, 2000, no. 1805-III]. Available at: https://zakon.rada.gov.ua/ laws/show/249/95-D0\%B2\%D1\%80?lang=en\#Text (accessed 26 July 2021). (in Ukrainian). 
17. Cyviljnyj kodeks Ukrajiny : Zakon Ukrajiny vid 16 sichnja 2003 roku, № 435-IV [Civil Code Ukraine of January 16, 2003, no. 435-IV]. Available at: https://zakon.rada.gov.ua/laws/show/435-15\#Text (accessed 27 July 2021). (in Ukrainian).

18. Tsyghanok O. B. (2018) Terminologhichni koliziji u leghaljnomu rusi ta obighu predmetiv mystectva j kuljturnykh cinnostej [Terminological Collisions in Legal Movement and Circulations of Art Objects and Cultural Property]. Mystectvoznavstvo Ukrajiny, no. 18, pp. 174-180. (in Ukrainian). 